\title{
磁気研磨法と炎の応用
}

\author{
進 村 武 男 \\ 宇都宮大学大学院工学研究科 凿 321-8585 栃木県宇都宮市陽東 7-1-2 \\ (2000 年 10 月 30 日受理)
}

\section{Magnetic Field Assisted Finishing Process and Its Industrial Applications}

Takeo SHINMURA

Graduate School of Engineering, Utsunomiya University

7-1-2 Yoto, Utsunomiya, Tochigi 321-8585

(Received October 30, 2000)

\begin{abstract}
Some combinations of different phenomena may cause unexpected yet rather beneficial effects. For instance, the combination of a magnetic field with the action of abrasive against a work material gives rise to a new magnetic field assisted finishing process, which shows the potential to overcome problems with more conventional surface finishing processes. Because magnetic flux flows without being impeded through nonferrous work material, it is possible to influence the abrasive acting force and the abrasive motion against a work surface by controlling the magnetic field. This causes the finishing operation not only on the easily accessible surfaces but also on the areas that are hard to reach by conventional mechanical techniques. This is a distinct advantage of magnetic field assisted finishing. This report presents the finishing principle, characteristics, and mechanism of the magnetic field assisted finishing process. In addition, a few examples of industrial applications are presented.
\end{abstract}

\section{1.は じめに}

「磁場」の概念を精密加工技術に取り込めば予期しな い新しい効果を発現できないだろうか。この発想を実現 するために，磁気援用加工法 (磁気研磨法, 2) ) を提案 し, 既成概念にとらわれない新技術の創出を目指して研 究を展開している。磁気を利用する新しい加工技術は, 磁束の流れ (磁力線) を媒介として磁性工具に加工力と 運動を発生させて精密部品の表面仕上げとエッジ仕上げ を実現する新技術である。

X 線が物体を透過する現象を利用して, 部品 (人体) を分解 (手術) することなしに部品 (人体) 内部の状況 (骨格) を観察 (診断) できるのと同樣に, 磁力線が非 磁性体を容易に透過する現象に着目し，部品内部に投入 した磁性工具に加工力と運動を与えて, 工具の加工挙動 を制御することができる。

E-mail: shinmura@cc.utsunomiya-u.ac.jp
したがって，磁気援用加工法の特長は，従来技術では 加工困難な箇所, すなわち, 通常の工具が入らない, 目 に見えない, 手が届かない箇所の精密加工に適用できる 技術であり，応用範囲と将来の発展もこの領域にあると 考えられる。

本稿は, 磁気研磨法の特長と, 2, 3 の応用事例につ いて述べる。

\section{2. 磁気援用加工法の特長}

磁力線に着目して乥の効果を利用する磁気援用加工法 を発展させるには, 加工法の特長を抽出・明確化して, 特長を集中的に利用することが大切である。この特長が， 既存技術を越える領域をもてば, 新技術として特有の守 備範囲をもち，生き残りが可能となる。

これまでの加工技術者の間では,「磁気」は単なる磁 力の利用 (磁気吸引力や磁気反発力の利用) にとどまっ ており，既存技術を改善する一手段として位置づけられ ていたに過ぎない。 
認識を新たにして『磁場という新たな場』を精密加工 技術に取り込み，新技術創出を意識的に志向して磁気利 用の考え方を確立できれば，従来技術では守備できない 加工対象物および加工箇所を比較的容易に加工可能なら しめ, 磁力線の作用効果に依存するしか他に加工手段が ない独自の精密加工領域を確立できるものと期待され る。磁気援用加工法は，従来技術と競合させるのではな く，従来技術が守備できない領域を拡大し得る新しい共 存技術として位置づけられる。

磁気援用加工法の特長は次の 4 点に集約できると考え ている。

(1) 磁力線の物体透過現象の利用

（2）磁力による磁性工具の加工力と運動の制御

(3) 磁力連結させた粒子ブラシの利用

（4）変動磁場を利用した磁気異方性工具の動的挙動の 活用

一般に，(1) から（3）の事象は単独で用いられるこ とはなく，組み合わされて特長が発揮される。

（1）は，X線が物体を透過する現象と同樣に磁力線は 非磁性体を簡単に透過する特性をもつ。例えば，Fig. 1 の閉じた矩形断面内部のような見えない, 手がとどかな い, 工具が入り難い箇所に磁性砥粒1 を投入して磁力に よって加工面に加工力と運動を与えることができる。

(2) は, Fig. 1 の加工力 $F x$ が, 磁力線の強弱度, す なわち, 磁場分布の不均一性に左右されることを示して いる。磁力 $F x$ は，

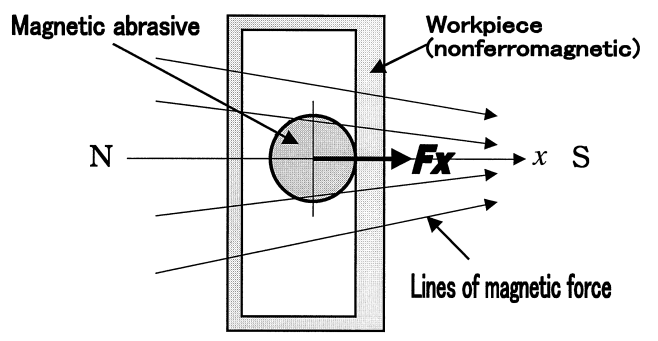

Fig. 1 Magnetic force $F x$ acting on a magnetic abrasive.

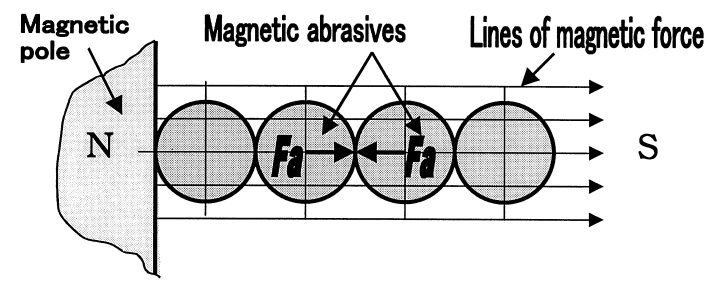

Fig. 2 Magnetic abrasive brush and its magnetic attraction force $F a$.

$$
F x=k V \chi H(d H / d x)
$$

ここに, $k$ : 係数, $H:$ 磁場強度, $(d H / d x):$ 磁場強度 の変化率, $V:$ 磁性砥粒の容積, $\chi:$ 磁性砥粒の磁化率 である゙2。

Fig. 1 の加工力方向 $(x$ 方向) に対して，弚の直角方 向の磁力は磁性砥粒に運動を与える方向であり，式 (1) の $x$ を $y$ に変換した同じ式で与えられる。

（3）は，Fig. 2 に示すように，磁場中の個々の磁性砥 粒は磁化されて $\mathrm{N}$ 極-S 極を形成し, 粒子同士が磁気吸 引し合い, 磁力線の方向に沿って数珠繋ぎ状の粒子ブラ シを形成する。この粒子ブラシは粒子相互の磁気吸引力 (Fig. 2 の Fa) が連結力となっているため, 分離・連結 が可能でフレキシブルな挙動をする。粒子ブラシの形成 は, 他の連続体ブラシ (ワイヤブラシやナイロンブラシ 等)では絶対に実現できない。

（4）は，変動磁場利用の新しい加工法 ${ }^{3}$ である。電磁 コイルに交流電流を通電させて閉じた非磁性工作物内部 に変動磁場を発生させ，投入した磁気異方性工具（ピン 工具) を工作物内部で三次元運動させて表面の改質と平 滑化を実現する手法である。ピン工具先端は工作物表面 を打撃して内面に圧縮残留応力を発生させ , ピン工具先 端のマイクロバニシ作用により表面が平滑化される。圧 縮残留応力の発生と表面の平滑化は疲労破壊強度を向上 させる゙่。

\section{3 . 磁極回転方式磁気研磨法}

\section{1 加工方法と装置}

半導体製造 - 原子力関連 - 医療 - 航空宇宙関連の各種 産業分野で高度のクリーン化技術が要求されている。ウ ルトラクリーン化技術の1つとしてクリーンガスボンベ やクリーンパイプの製造技術がある。高純度ガスは貯蔵 中およひ輸送中の污染を極度に嫌うため, 容器およびパ イプ内面の精密洗浄と污染物滞留防止のため, 内面には $0.2 \mu \mathrm{m} R y$ 以下 (Ry : 表面粗さの表示法の 1 つであり， 粗さ断面曲線から求められる最大高さ粗さ(JIS B0601), $\mu \mathrm{m}$ : マイクロメートル) の高精度表面が要求されてい る。

クリーンパイプは細長く（内径 2〜 $100 \mathrm{~mm}$, 長さ 2 $4 \mathrm{~m})$, 曲がり管も多いため, パイプを高速回転させる ことができない。したがって, 通常の内面研磨法の適用 は難しく，新しい研磨法の開発が切望されている。筆者 らはこの社会ニーズに応え得る新しい内面研磨技術の開 発に成功した ${ }^{4,5)}$ 。

Fig. 3 に, 磁極回転方式内面磁気研磨法の加工部模式 図を示す。永久磁石の $\mathrm{N}$ 極から発した磁力線は, 非磁 性円管（クリーンパイプ）を透過し，円管内部に磁気を 


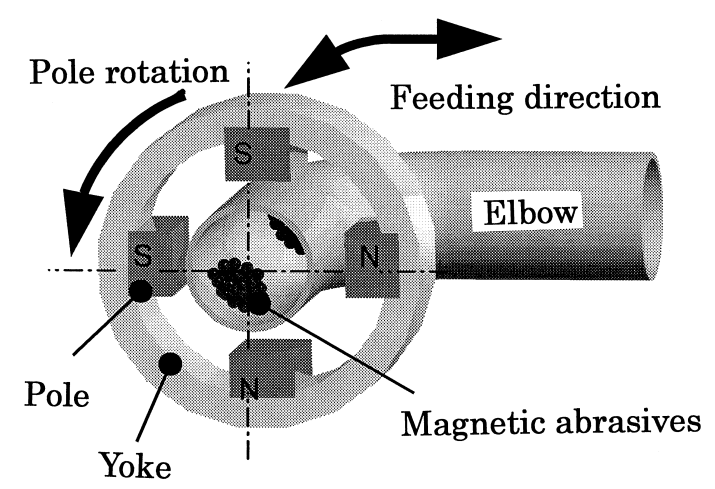

Fig. 3 Schematic of internal magnetic abrasive finishing process by pole rotation system for bent tubes.

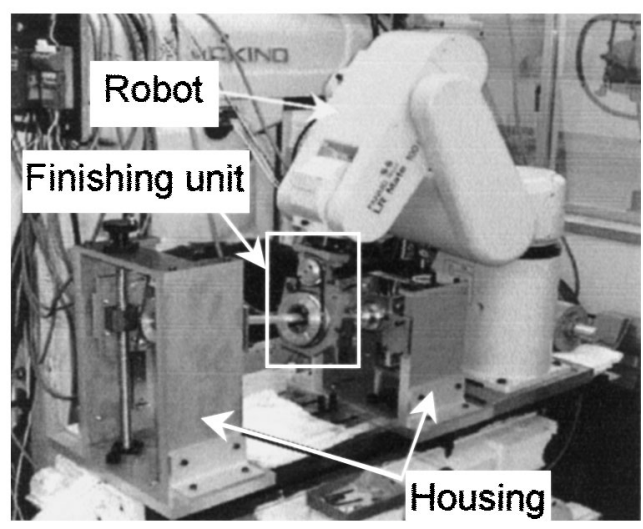

Fig. 4 External view of experimental setup.

作用させて $\mathrm{S}$ 極に戻る。円管端から投入した磁性砥粒 群は円管外に設置した磁極に磁気吸引され，円管内面に 研磨力を生ずる。

次に, 磁極を高速回転させると磁性砥粒群は接線研磨 抵抗を受けるが，磁極近傍の強い磁力によって回転駆動 力を受けて回転磁極に追従して回転し，円管内面との間 に相対運動を発生する。

高速回転する磁極を円管の軸方向に沿って移動してい けば，円管内面の全面が精密に研磨加工できる。この磁 極回転方式によれば円管を回転させる必要がなく，直管 はもちろん，Fig. 3のような曲がり管にも適用できる。 また，円管の長さに制限がない特長をもつ。加工装置も 小形軽量である。

Fig. 3 の加工ユニットを製作して 5 軸制御ロボットの アーム先端に取り付け, SUS 304 (オーステナイト系ス テンレス鋼) 材のエルボ (曲がり管) の軸方向に移動し て内面の鏡面仕上げを実現している樣子をFig. 4 に , 加 工部ユニットの拡大写真を Fig. 5 に示す。磁極にレアア

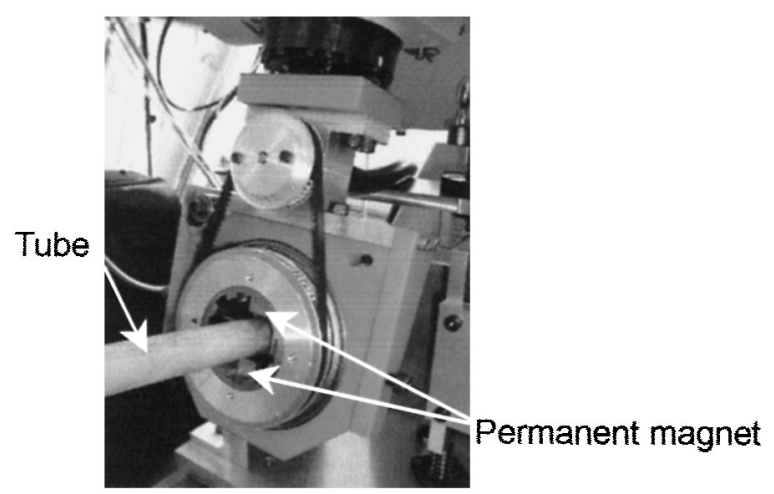

Fig. 5 Enlargement of finishing unit.

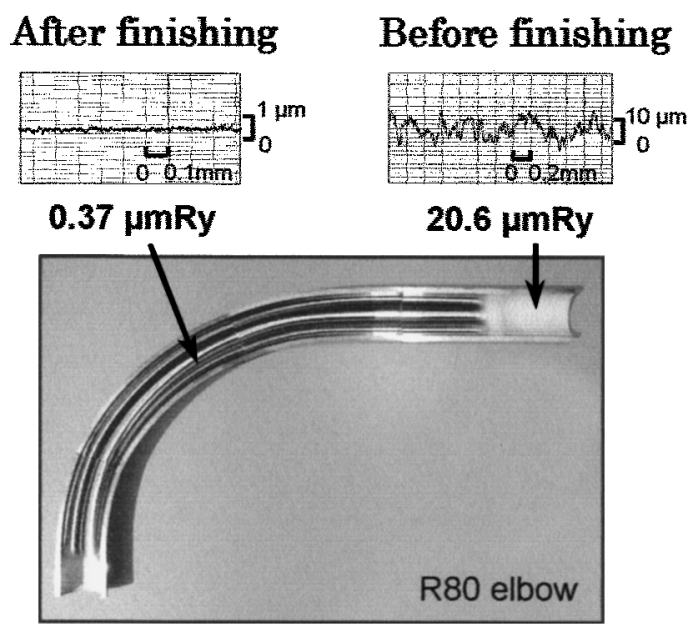

Fig. 6 Photo and surface roughness profiles of inner surface of R80 elbow after finishing.

一ス永久磁石 (Nd-Fe-B 永久磁石)を用いた。

SUS 304 ステンレス鋼エルボ管内面の加工後の外観写 真と表面粗さプロフィルを Fig. 6 に示す5)。加工後の工 ルボ管を2つ割りにして示した。内面は鏡面に仕上げら れており，加工前の粗さ $20.6 \mu \mathrm{m} R y$ を $0.37 \mu \mathrm{m} R y$ に仕上 げることに成功した。この磁極回転方式内面研磨法は大 型旅客機などの航空宇宙産業の配管系内面の精密仕上げ 等に実用されている6゙。

\section{2 表面の創成機構}

磁性砥粒を用いる磁気援用内面研磨法の表面創成機構 は, 磁性砥粒に含有されている研磨材の微小な切削作用 の集積によって創成されることがわかっている7。

本項では, 専用の磁性砥粒1を用いる加工法に限定し ないで，磁性砥粒の代わりに各種の磁性粒子(鉄粉など) と各種の遊離砥粒を用いることができるスラリー循環方 
式内面磁気研磨法 ${ }^{8}$ の表面創成機構について述べる。ス ラリー循環方式は, 砥粒をスラリー状にして磁性粒子と ともに円管加工部に供給循環させ , 磁性粒子に加工力と 回転運動を与えて内面を仕上げる方法である ${ }^{8)}$ 。

磁性粒子には, 電解鉄粉 ( $\mathrm{Fe}: 99 \%$, 平均粒径 $510 \mu \mathrm{m}$ ) を基準に，形状と磁気特性が異なる 3 種類の磁性粒子， すなわち機械構造用炭素鋼鋼材 S48C (JIS G 4501) ピン $(\phi 0.5 \times 5 \mathrm{~mm})$ と SUS 304 ステンレス鋼 (JIS G 4303) ピン ( $\phi 0.5 \times 0.5 \mathrm{~mm}, \phi 0.5 \times 5 \mathrm{~mm})$ を準備した。実験 装置はFig. 3 とほぼ同じである[詳細は文献 8)を参照]。 これら 4 種類の磁性粒子を用いて SUS 304 ステンレス 鋼円管の内面研磨実験を行い, 加工面をSEM 観察した。

Fig. 7 に, 加工前後の SEM 写真を示す。加工時間は 50 分間である。電解鉄粉と S48C 炭素鋼ピンは, 磁性粒子 間を流動するスラリー (砈粒) を加工面に押し付けなが ら磁極に追従回転し, 加工作用に関与する。磁性粒子に 押し付けられた砥粒が, 方向性のある微小切削を主体と して表面を平滑化したものと考えられる (Fig.7 (b) , (c))。

一方, SUS 304 ステンレス鋼ピンは, 電解鉄粉や S48C 炭素鋼ピンに比べて低磁力しか発生できないが, ピンの 数珠間を流れるスラリーの流動性は良い。したがって， ピンはスラリーを加工面に押し付けるよりも，むしろス ラリーを巻き込む際に砥粒を加工面に衝突させ, 方向性 のない切削痕を生成して, 加工面を平滑化したと推察さ
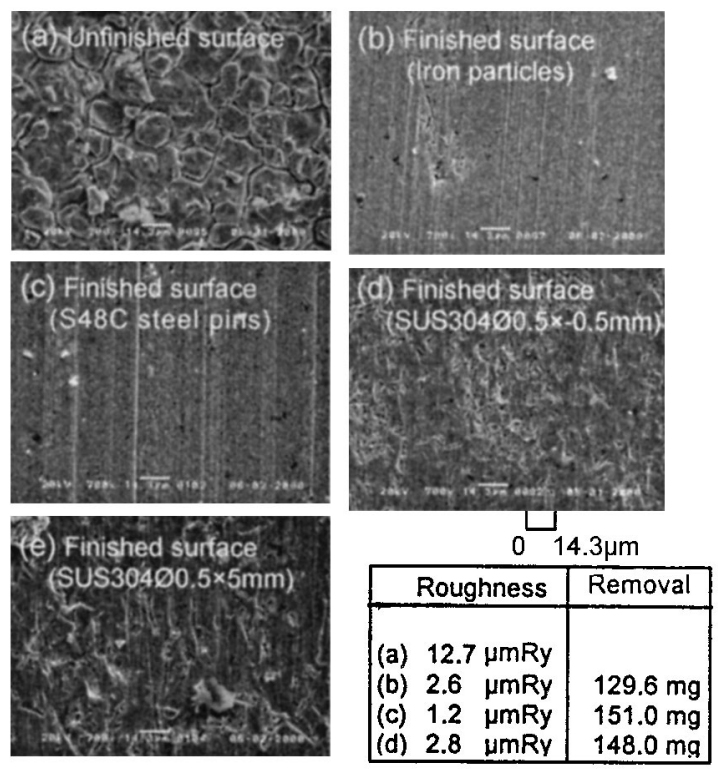

Fig. 7 SEM photos of inner surface of the tube before and after finishing in $50 \mathrm{~min}$.
れる (Fig.7 (d)，(e))。図示していないが, この挙動 のために, 電解鉄粉や S48C 炭素鋼ピンに比べて, SUS 304 ピンの加工量は高くなっている ${ }^{8)}$ 。

\section{3 電解研磨面への適用}

クリーンパイプの最終仕上げ技術として電解研磨法が ある。電解研磨法は加工面を電気化学的に溶出して表面 を平滑化することを原理としており，極く微細な表面凹 凸の除去を得意としている。反面, 比較的波長の長い凹 凸面は除去できない。このため, 通常の電解条件では 0.05 $\mu \mathrm{m} R a$ 程度 ( $R a$ : 表面粗さの表示法の 1 つであり，粗さ 断面曲線から求められる算術平均粗さ (JIS B0601)) の 仕上げを限界としている。

本項は, 電解研磨法によって仕上げられたステンレス 鋼円管 (SUS $304, \phi 12.7 \times \phi 11.2 \mathrm{~mm}$, 加工幅 $15 \mathrm{~mm}$ ) を用いて , スラリ一方式内面磁気研磨実験を試み , 到達 加工面粗さを調べた結果について述べる9”。実験装置は Fig. 3 と基本的に同じ構成である ${ }^{9)}$ 。平均径 $0.5 \mu \mathrm{m}$ のダ イヤモンド砥粒を用い, 鉄粉とダイヤモンド砥粒の混合 重量比はを $2: 1$ として実験した。実験条件を Table 1 に 示す。

最初に，電解研磨面に対する鉄粉径の影響と混入する 砈粒径の影響を調べた。結果を図示していないが，鉄粉 径 $43 \mu \mathrm{m}$ で砥粒径が $10 \mu \mathrm{m}$ 以下のときに電解研磨面を 改善できることがわかった。従来のSUS 304 円管内面 の磁気研磨実験によれば, $330 \mu \mathrm{m}$ 径の鉄粉に $5 \mu \mathrm{m}$ 径の WA 砥粒（酸化アルミニウム $\mathrm{Al}_{2} \mathrm{O}_{3}$ を主成分とする研磨 材の一種で, 遊離砥粒だけでなく，固定砥粒としてもよ 〈使用される) を混合して加工した場合でも，15 $\mu \mathrm{m} R y$ の前加工面粗さを $0.2 \mu \mathrm{m} R y$ に仕上げられている4,7)。こ の加工機構は明確になっていない。磁気援用加工法によ

Table 1 Experimental conditions.

\begin{tabular}{|c|c|}
\hline Workpiece & $\begin{array}{l}\text { Material: SUS } 304 \text { tube } \\
\text { Size: } \phi 12.7 \times \phi 11.8 \mathrm{~mm} \\
\text { Finished length: } 15 \mathrm{~mm} \\
\text { Initial surface roughness: } 0.052 \mu \mathrm{mRa}\end{array}$ \\
\hline Magnetic pole & $\begin{array}{l}\text { Material: Nd-Fe-B rare earth } \\
\text { permanent magnet } \\
\text { Size: } 12 \times 14 \times 16 \mathrm{~mm} \\
\text { (magnetized in the direction of } 12 \mathrm{~mm} \text { ) } \\
\text { Arrangement: } \mathrm{N}-\mathrm{S} \text { poles } 180^{\circ} \\
\text { Revolution: } 1200 \mathrm{~min}^{-1}\end{array}$ \\
\hline Abrasive slurry & $\begin{array}{l}\text { Basic fluid: light oil } \\
\text { Abrasive: diamond grains } 0.5 \mu \mathrm{m} \\
\text { Supplied amount: } 0.5 \mathrm{~g}\end{array}$ \\
\hline Iron particle & $\begin{array}{l}\text { Mean diameter: } 43 \mu \mathrm{m} \\
\text { Supplied amount: } 1 \mathrm{~g}\end{array}$ \\
\hline Finishing time & $5 \mathrm{~min}$ \\
\hline
\end{tabular}




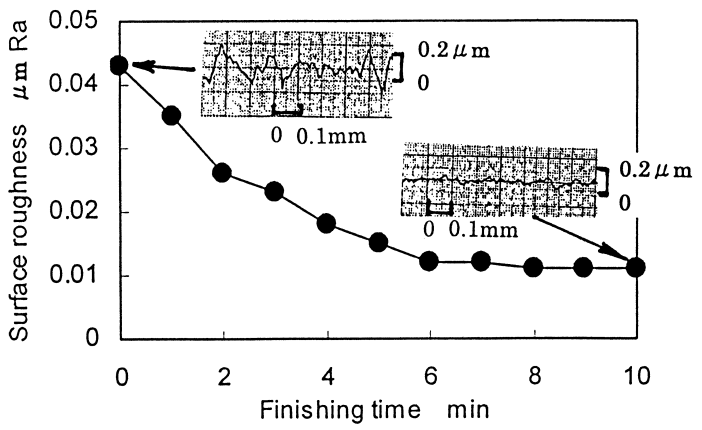

Fig. 8 Relationship between surface roughness and finishing time.

る加工面は, 他の砥粒加工法で見られる砥粒径と加工面 粗さの関係とは多少異なった機構によって得られるよう である。

Fig. 8 に $43 \mu \mathrm{m}$ 径鉄粉と $0.5 \mu \mathrm{m}$ 径ダイヤモンド砥粒 を用い，電解研磨面を磁気研磨したときの加工面粗さの 時間的変化を示す。Fig. 8 には加工前と $10 \mathrm{~min}$ 間加工後 の表面粗さプロフィルも示した。加工時間 6 min で初期 の電解研磨面は改善され，一定值に落ち着く。加工前の 粗さ $0.043 \mu \mathrm{mRa}$ を $0.01 \mu \mathrm{mR} a$ の精密表面に改善でき た。

加工前後の表面プロフィルから, 加工前の電解研磨面 には電解研磨特有のゆるやかで大きな山が観察されるの に対して，加工後の磁気研磨面は平滑化と共に砥粒加工 特有の微細凹凸面が観察される。この事象から，機械的 な砥粒加工を基本とする磁気援用加工法は電解面に対し ても有効であるといえる。

\section{4 . 粒子ブラシの利用}

磁気援用加工技術の他の特長は, Fig. 2 に示す粒子ブ ラシの利用にある。Fig. 9 左図のように, N-S 磁極間に 磁性粒子を投入すると, 粒子は磁力線に沿って数珠繋ぎ 状に連結する。Fig. 9 左図は工作物扦入前の粒子ブラシ の状態を表しており，右图は工作物（例えば，コンピュ 一夕磁気ディスク装置のアクセスアーム) を挿入して加 エしている状態を示している。磁力線の非磁性体に対す る透過現象を利用して, 分離・連結が容易で, フレキシ ブルな挙動をする粒子ブラシの特長を生かし, 複雑形状 部品の狭い箇所の内面加工を実現できる ${ }^{10}$ 。

Fig. 10 はコンピュータ磁気ディスク装置に用いられ るアクセスアームを示しており，形状は櫛歯形をしてい る。櫛歯先端に磁気ヘッドが取り付けられる。このアク セスアームには高い形状精度と面積度が要求されてい る。しかし , 材質が柔らかいアルミニウム合金であるこ

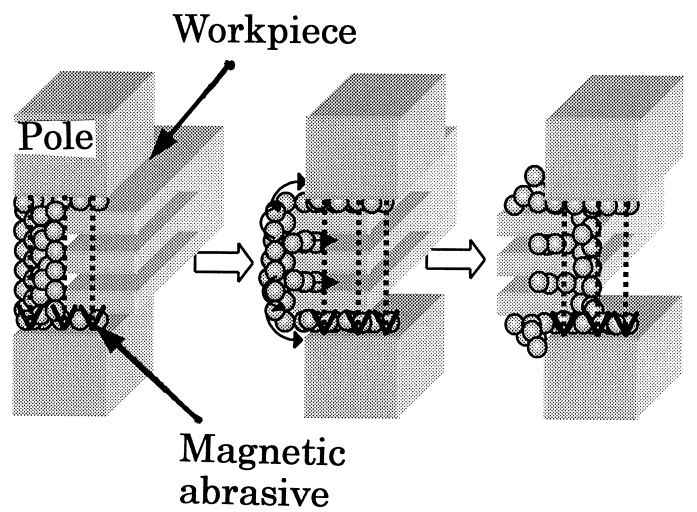

Fig. 9 Behaviors of magnetic abrasive particles.

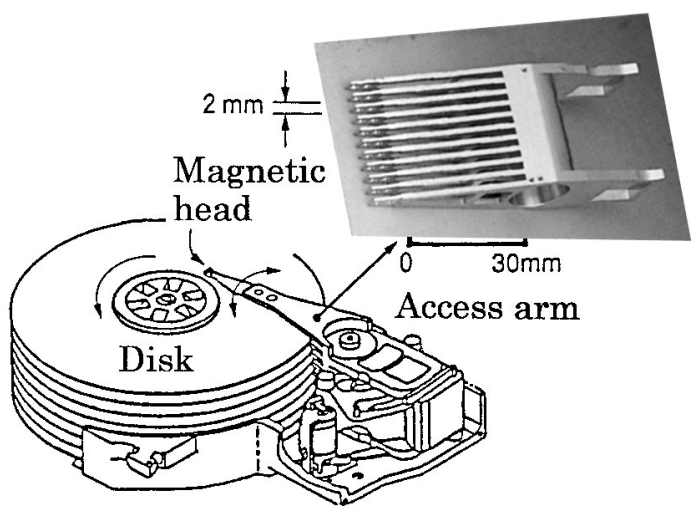

Fig. 10 Hard disk drive (HDD) unit.

と，アームが細長い櫛歯形をしているために，アーム全 体の形状精度を維持しながら同時に多数の櫛歯の内外面 を高精度に仕上げることは非常に難しく，月産数十万個 といわれる数のアクセスアームの最終仕上げは人手に依 存しているところも多い。

結論から先にいえば，磁気援用加工技術に着目したこ とによって，アクセスアームの最終仕上げ加工（精密バ リ取り) を自動化・省力化・高品質化することに成功し ている"1)。

Fig. 11 はアクセスアーム先端の加工前後の顕微鏡写 真である ${ }^{11)}$ 。機械加工後のアームのエッジには切削加工 による微小バリが生成され，加工面も粗い。磁気研磨法 の適用により，精密なエッジ仕上げと表面仕上げが実現 されていることがわかる。

ハイテク産業部品にはアクセスアームのような非磁性 材料も多く用いられており, 磁気 (磁力線) を容易に透 過する。磁力線の物体透過現象をうまく利用すれば，ア クセスアームのような複雑形状部品で, 通常の加工工具 


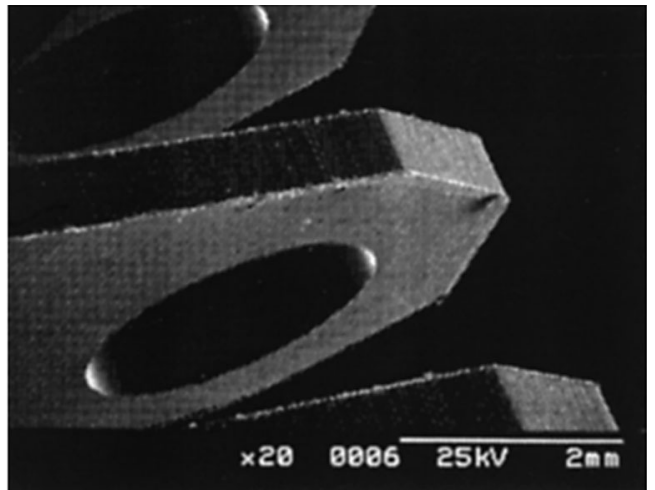

(a) Before deburring

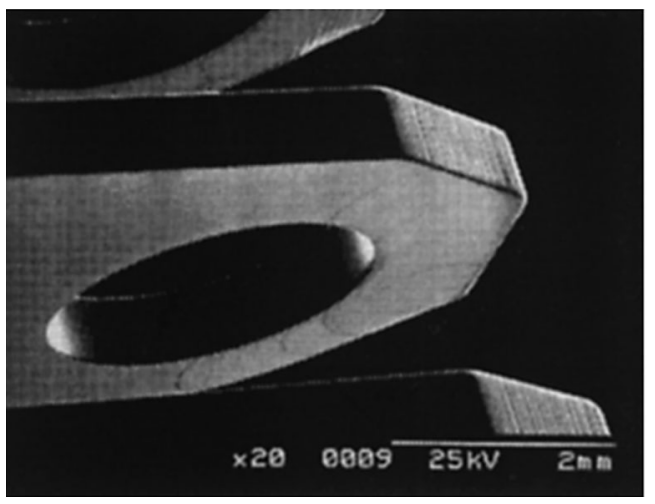

(b) After deburring

Fig. 11 SEM photos of HDD access arm before and after deburring.

が入らない, 人の手が届かない, 見えない箇所で, しか も高精度加工を必要とする各種部品に適応できる新しい 精密仕上げ技術が実現できよう。

\section{5.おわりに}

磁気援用加工法 (磁気研磨法) の特長, 2, 3 の応用 事例について述べた。磁気援用加工法は従来法では加工 困難とされる細長い円管や曲がり管の内面などの入り組 んだ狭い箇所など, 通常の加工工具や人手が入り難くて 見えない箇所の精密仕上げに適用できる。また，新しい 表面改質技術 (圧縮残留応力の発生と表面硬化技術 ${ }^{12,}{ }^{13}$ ) としての応用性を秘めている。

今後，実用化の事例も増え，磁気援用加工法が $1 つ の$ 新しい精密加工技術として発展することを念願してい る。

\section{文献}

1) 進村武男, 高沢孝哉, 波田野栄十 : 精密工学会誌 52, 851(1986).

2) 精密工学会編 ! “精密工作便覧” (コロナ社 ,1992) p.1 及び p. 441.

3) 進村武男, 山口ひとみ : 精密工学会秋季大会学術講 演会講演論文集 (1999) p. 216.

4) H.Yamaguchi, T. Shinmura and T.Kaneko: Int.J. Japan Soc. Prec. Eng. 30, 317 (1996).

5) 山口ひとみ, 進村武男, 小林 厚 : 日本機械学会年 次大会講演論文集 (V) (No. 99-1) (1999) p. 53.

6) 共栄電工株式会社からの私信 .

7) H.Yamaguchi and T. Shinmura: WEAR 225-229, 246 (1999).

8) 山口ひとみ, 進村武男 : 精密工学会秋季大会学術講 演会講演論文集 (2000) p. 201.

9) 進村武男, 渡辺将人: 精密工学会春季大会学術講演 会講演論文集 (1997) p. 201.

10) 進村武男, 山口ひとみ : 精密工学会秋季大会学術講 演会講演論文集 (1999) p. 215.

11) 共栄電工株式会社 : 技術資料.

12) 山口ひとみ, 進村武男 : 精密工学会秋季大会学術講 演会講演論文集 (1999) p. 216.

13）参考として，広瀬正吉 :“ショットピーニング” (誠 文堂新光社, 1964) p. 141. 